\title{
SEBERAPA PANJANG LONGUE DUREE? CATATAN TENTANG LONGUE DUREE DALAM PRAKTIK PENULISAN SEJARAH
}

\author{
Gani A. Jaelani \\ Departemen Sejarah \& Filologi, Fakultas Ilmu Budaya \\ Universitas Padjadjaran \\ gani.jaelani@unpad.ac.id
}

\begin{abstract}
Abstrak
Artikel ini dimaksudkan untuk menganalisis konsep longue durée dalam praktik penulisan sejarah. Sejak diperkenalkan oleh Fernand Braudel pada tahun 1958, ia terus menjadi bahan perdebatan dalam praktik penulisan sejarah di tingkat global. Berbagai kritik maupun apresiasi terhadap perspektif ini bisa ditemui dalam berbagai literatur tentang historiografi. Meskipun demikian, penjelasan mengenai apa itu longue durée sering kali absen dalam pembahasan, sehingga penggunaan istilah ini sering kali tidak seragam. Atas dasar itu, artikel ini akan membahas konteks sosial politik kelahiran longue durée. Selain itu, artikel ini juga akan membahas apa itu longue durée dan bagaimana ia dimaknai. Terakhir, artikel ini juga akan menganalisis reaksi yang muncul terhadapnya dan semangat untuk kembali kepadanya sebagai upaya untuk mengaktualisasi kajian ilmu sosial, terutama kajian disiplin sejarah.
\end{abstract}

Kata kunci: Fernand Braudel, Historiografi, Longue durée, Mazhab Annales

Abstract

This article aims to analyze the concept of longue durée in the practice of historical writing. This concept has been discussed on a global scale since being introduced by Fernand Braudel in 1958. Critiques and appreciations of this perspective are found in many pieces of literature about historiography. However, the explanation about what longue durée is often absent in the debate, and this concept has had always different meanings. Based on that issue, this article will explain what longue durée is and how it is responded by historians. The social and political contexts of the emergence of this concept will also be analyzed. Lastly, this article will analyze the reaction to the concept and the tendency to return to that perspective in historical writing.

Keywords: Fernand Braudel, Historiography, Longue durée, The Annales school

\section{PENDAHULUAN}

Dalam praktik penulisan sejarah, istilah longue durée bukan sesuatu yang asing. Ia telah menjadi bahan perdebatan sejak diperkenalkan pada tahun 1958 oleh Fernand Braudel, baik di negara tempat kelahirannya, yakni Prancis, maupun di negara-negara berbahasa Inggris. Beberapa sejarawan menjadikannya sebagai kerangka analisis, sementara ilmuan lainnya mengkritik. Perdebatan yang terjadi di seputarnya juga telah mengubah cara bagaimana sejarah ditulis dan oleh sebabnya ikut mengubah status disiplin ilmu sejarah itu sendiri. Itulah mengapa, ulasan 
tentang apa itu longue durée, konteks sosial politik yang menjadi latar kelahirannya, dan bagaimana ia dibicarakan dari masa ke masa menjadi penting untuk dilakukan. Kajian tentang ini bukan belum pernah dilakukan. Dalam literatur berbahasa Inggris dan Prancis sudah ada banyak ulasan tentang permasalahan ini.

Tulisan Michel Vovelle yang berjudul "L'histoire et la longue durée" yang terbit tahun 1978 dalam kumpulan tulisan berjudul La nouvelle histoire merupakan sebuah artikel yang secara khusus menganalisis apa itu longue durée dalam hubungannya dengan praktik penulisan sejarah di Prancis. Artikel ini cukup penting sebagai pijakan awal untuk mengelaborasi permasalahan longue durée. Hanya saja, sintesis yang dilakukan oleh Vovelle dalam artikel ini tidak mengurai lebih jauh konteks kemunculan longue durée yang sering dihubungkan dengan adanya krisis ilmu-ilmu sosial, sebuah permasalahan yang dibahas dengan cukup baik oleh Immanuel Wallerstein dalam artikelnya "Braudel on the Longue Durée: Problems of Conceptual Translation", terbit tahun 2009 dalam jurnal Review (Fernand Braudel Center). Artikel ini ditulis sebagai pengantar terhadap terjemahan baru artikel klasik Braudel tentang longue durée yang dilakukan oleh Wallerstein sendiri. Di dalamnya, ia mencoba mengklarifikasi beberapa istilah kunci, dan dalam waktu bersamaan, memberi konteks kelahiran artikel Braudel. Sebagai sebuah tulisan yang memang ditujukan untuk memberi konteks terhadap kelahiran artikel yang diterjemahkannya, ia memiliki informasi yang banyak. Hanya saja, artikel Wallerstein ini tidak terlalu membahas respons yang muncul atas diperkenalkannya perspektif longue durée ini dalam praktik penulisan sejarah. Tulisan Dale Tomich "The Order of Historical Time: The Longue Durée and Micro-History", terbit tahun 2011 dalam jurnal Almanach merupakan artikel penting yang mengulas persoalan itu. Kekurangan yang ada dalam artikel ini adalah ia tidak membahas gagasan konseptual longue durée itu sendiri secara rinci, yang nantinya akan menjadi fokus utama tulisan ini. David Armitage dan Jo Guldi menerbitkan The History Manifesto pada tahun 2014 sebagai sebuah ajakan memikirkan kembali penerapan perspektif longue durée dalam praktik penulisan sejarah untuk menghadapi krisis yang sedang dialami oleh ilmu-ilmu sosial kontemporer. Ide yang kemudian menjadi tema khusus jurnal Annales tahun 2015 ini lebih merupakan sebuah ajakan dialog antara ilmu-ilmu sosial, sebuah gagasan yang juga melatari lahirnya tulisan Braudel tentang longue durée itu sendiri di tahun 1958. Oleh karenanya, kedua sejarawan ini tidak banyak membicarakan detil tentang apa yang dimaksud dengan longue durée itu sendiri.

Dalam literatur berbahasa Indonesia pembahasan mengenai hal ini bisa dikatakan hampir tidak ada. Memang gagasan longue durée pernah disinggung di sana $\operatorname{sini}^{1}$, tetapi ia belum pernah menjadi sebuah kajian khusus. Itulah mengapa,

\footnotetext{
1 Penyebutan longue durée secara sepintas bisa dibaca di dalam buku Pendekatan Ilmu Sosial dalam Metodologi Sejarah karya Sartono Kartodirdjo. Mazhab Annales, kerap disebut dalam tulisan-tulisannya, sekalipun rujukan terhadapnya juga cukup terbatas. Misalnya, sekalipun ia kerap mengutip Braudel, tentang tiga lapisan waktu dan juga kritiknya terhadap praktik penulisan sejarah événementiel, dalam daftar pustaka tidak ditemukan rujukan ke karya Fernand Braudel secara langsung. Di dalam daftar pustaka, terdapat hanya dua sejarawan Prancis yang dijadikan rujukan, yakni H. I. Marrou dan Michel Vovelle dan satu filsuf Prancis Raymond Aron (Lihat Kartodirdjo, 1993, p. 81 dan 115). Dalam uraian yang sedikit panjang, persoalan longue durée bisa dibaca dalam buku Kuntowjiyo yang berjudul Penjelasan Sejarah (2008). Ia memberi contoh beberapa karya dalam historiografi Indonesia yang termasuk ke
} 
artikel ini menjadi sangat penting untuk ditulis. Pertama, artikel ini bertujuan untuk memperkaya perdebatan historiografi dalam kajian sejarah di Indonesia, dengan membuat analisis mendalam terkait longue durée; kedua, meletakkan Indonesia dalam perdebatan istilah ini, mengingat adanya keinginan untuk mengembalikan longue duree dalam kajian sejarah yang bahkan dianggap bisa menjadi solusi atas kebuntuan kajian sejarah sekarang yang kurang bisa menjawab krisis yang dihadapi oleh ilmuilmu humaniora.

\section{METODE PENELITIAN}

Tulisan ini merupakan sebuah penelitian historiografi. Berbeda dari kajian sejarah empiris yang tujuannya adalah rekonstruksi peristiwa yang terjadi di masa lalu, penelitian ini menitikberatkan pembahasan di ulasan tulisan-tulisan sejarah, terkait cara bagaimana seorang sejarawan merekonstruksi masa lalu, paradigma yang dipergunakan, sampai ke konsep-konsep dasar yang dioperasikan dalam proses rekonstruksinya. Tulisan ini akan membahas konsep longue durée sebagai sebuah konsep ilmiah yang sering dioperasikan dalam kajian ilmu sejarah. Dengan kata lain, tulisan ini akan membahas sejarah konsep ilmiah mengikuti kerangka berpikir epistemologi sejarah yang digunakan oleh Canguilheim (Rheinberger, 2010: 65-69).

Tulisan ini dengan demikian akan membahas artikel yang ditulis oleh Fernand Braudel pada tahun 1958, dan tulisan-tulisan lainnya yang memberi penjelasan konteks kemunculan artikel tersebut. Selain itu, artikel ini juga akan membahas bagaimana tulisan-tulisan yang mengulas pemikiran Fernand Braudel untuk melihat sejauh mana para ilmuan kemudian membicarakan pemikiran tersebut. Semua ini dilakukan untuk melihat bahwa pada akhirnya, gagasan longue durée yang diperkenalkan oleh inisiatornya berkembang lebih jauh dari apa yang digagas di awal. Demikian, artikel ini lebih merupakan sebuah sintesis dari tulisantulisan yang pernah ada, untuk kemudian dilihat dalam hubungannya dengan apa yang bisa dilakukan dalam konteks saat ini dengan konsep itu.

\section{HASIL DAN PEMBAHASAN}

\subsection{Fernand Braudel dan longue durée}

Istilah longue durée yang diperkenalkan oleh Fernand Braudel pada tahun 1958 sebetulnya memiliki akar yang lebih panjang sampai ke akhir abad ke-19. Setidaknya, ada tiga karya yang menggunakan dua kata itu di dalam judulnya (Armitage \& Guldi, 2015b: 367)2. Meskipun demikian, apa yang ditawarkan oleh ketiga karya itu, tentu

\footnotetext{
dalam perspektif longue durée. Hanya saja pemahaman tentang istilah ini masih terpaku di durasi panjang semata (Lihat Kuntowijoyo, 2008 terutama halaman 26 dan 62), permasalahan yang menjadi pokok bahasan dalam artikel saya ini. Pembahasan longue durée dalam praktik penulisan sejarah di Indonesia, oleh sebabnya, perlu pembahasan tersendiri.

2 Menurut David Armitage dan Jo Guldi, ketiga karya tersebut adalah: Eugène Garsonet, Histoire des locations perpétuelles et des baux à longue durée, Paris, L. Larose, 1878 ; Victor Lamaitre, Considérations sur la paralysie générale de longue durée, Paris, A. Parent, 1879 ; Gaston Imbert, Des mouvements de longue durée Kondratieff, 3 vol., Aix-en-Provence, Pensée universitaire, 1956.
} 
saja tidak sama dengan yang ditawarkan oleh Braudel. Dengan kata lain, sekalipun menggunakan istilah yang sama, pemaknaan yang diberikan terhadapnya sangat berbeda. Istilah longue durée yang disampaikan oleh Braudel-lah yang kemudian menjadi bahan perdebatan dalam kajian sejarah. Meskipun demikian, dalam perkembangannya, pemaknaan terhadapnya juga mengalami perubahan.

Pada saat Braudel menerbitkan artikelnya yang berjudul "Histoire et Sciences Sociales: La longue durée" pada tahun 1958 dalam jurnal Annales, Economies, Sociétés, Civilisations, ia sedang bereaksi terhadap krisis ilmu-ilmu sosial dan humaniora pada saat itu $^{3}$. Hal ini bisa dilihat dengan jelas pada kalimat pembuka yang disampaikannya: "Ada krisis yang umum [terjadi] dalam kajian ilmu humaniora". Dan jalan keluar dari persoalan ini adalah sebuah kerja kolektif dari rumpun ilmu humaniora itu sendiri di bawah panduan ilmu sejarah. Karena ilmu sejarah pada waktu itu dianggap hanya berkutat di persoalan-persoalan individu, peristiwaperistiwa individual yang sering kali tidak dilihat sebagai satu kesatuan, Braudel kemudian menawarkan cara pandang dengan mengenalkan paradigma longue durée.

Apa yang dilakukan oleh Braudel ini merupakan sebuah refleksi teoretis dari karyanya yang diterbitkan sembilan tahun sebelumnya, La Méditerranée et le monde méditerranéen à l'époque de Philippe II (1949). Tulisan yang terdiri dari tiga bagian ini , sekalipun ia sama sekali tidak menyebutkan istilah longue durée dan hanya sekali menyebut événementiel (Noiriel, 2003: 123), sungguh merepresentasikan tiga lapisan waktu yang dikonseptualisasi dalam artikelnya yang terbit tahun 1958 tadi: longue durée, conjoncturel, événementiel. Sementara itu, La Méditerranée, yang merupakan karya besar Braudel, merupakan buah dari perenungannya ketika ia berada di penjara Jerman pada masa Perang Dunia II. Ia dipenjara ketika sedang menjalankan tugas negara sebagai tentara di perbatasan Rhine: pertama di Mainz, dari tahun 1940 1942, dan kemudian di Lübeck, dari tahun 1942-1945. Selama periode ini, ia banyak memikirkan subjek penelitiannya tentang Méditerranée yang sudah dikumpulkan sejak awal tahun 1930-an. Draf awal buku ini juga ia tulis di penjara dan dikirimkan ke Lucien Febvre, teman sekaligus mentornya yang juga salah satu dari dua orang pendiri jurnal Annales yang dalam perkembangannya menjadi sebuah aliran dalam praktik penulisan sejarah (Braudel, 1972: 452-453). Kondisi penjara tidak memungkinkan dirinya membawa material penelitian yang telah dikumpulkannya selama bertahun-tahun, dan karena itulah, ia menulis draf awal La Méditteranée didasarkan pada ingatan (Braudel, 1992: 238). Pada saat inilah ide tentang waktu yang bergerak lambat, berjalan dalam proses yang panjang, yang kemudian menjadi prakondisi waktu yang bergerak cepat, muncul ke permukaan. Paule Braudel, istri sang sejarawan, dalam kesaksiannya mengatakan bahwa La Méditerranée lahir dari dua kondisi yang sangat spesifik: proses pendewasaan keilmuan yang berjalan lambat dan penuh kesendirian yang dimungkinkan oleh kondisi penjara; di sisi lain, ia juga merupakan buah dari kehidupan universitas yang marginal yang dialami Braudel (Braudel, 1992: 238).

\footnotetext{
3 Perlu disampaikan bahwa istilah ilmu sosial dan ilmu humaniora dalam tradisi Prancis merupakan sebuah entitas yang serupa tapi tak sama. Dalam artikel Braudel itu sendiri, kedua istilah itu kerap dipertukarkan. Itulah sebabnya sekalipun dalam judul Braudel menyebut "Sejarah dan Ilmu Sosial", tetapi kalimat pembuka dalam tulisannya menyebut tentang krisis ilmu humaniora. Penjelasan lebih jauh tentang hal ini, lihat Wallerstein (2009).
} 
Artikel Braudel tentang longue durée ini kemudian menjadi rujukan dari apa yang dinamai sebagai analisis struktural dari sejarah yang menginginkan supaya penjelasan dari peristiwa sejarah itu tidak hanya di permukaan, tetapi bisa melihat elemen-elemen yang memungkinkan apa yang di permukaan itu terbentuk, dengan cara melakukan analisis struktural (Pomian, 1978; Dosse, 2014). Dengan demikian, karya sejarah bisa memberikan sesuatu yang lebih dari sekedar mengabarkan peristiwa yang terjadi di masa lalu dan karenanya, lebih bisa berdialog dengan ilmuilmu sosial yang lain, karena karya sejarah juga bisa memberi penjelasan atas peristiwa yang terjadi di permukaan dan mengapa itu bisa terjadi. Pemikiran ini sejalan dengan aforisma Lucien Febvre yang kerap dijadikan rujukan dalam praktik penulisan sejarah, bahwa "sejarah adalah ilmu tentang masa lalu, ilmu tentang masa kini" - "science du passé, science du présent"(Wallerstein, 1978: 5; lihat juga Febvre, 1949) ${ }^{4}$. Lebih dari itu, dengan memberi penjelasan tentang lapisan waktu, dan pentingnya melakukan analisis dalam kerangka longue durée, Braudel berharap bahwa kajiannya akan banyak menarik minat para ilmuan sosial, yang darinya sebuah kajian multidisipliner bisa terwujud: sebuah ikhtiar untuk mengatasi krisis ilmu sosial itu sendiri.

\subsection{Konteks: Krisis Ilmu Sosial dan Tantangan Strukturalisme}

Ada beberapa hal yang perlu diperhatikan terkait penerbitan artikel Braudel yang menjadi pembahasan dalam tulisan ini. Hal tersebut perlu dilakukan untuk memperjelas apa yang menjadi ambisi Braudel ketika menulisnya.

Pertama, artikel ini merupakan sebuah produk pemikiran Prancis di tahun 1950an. Pada periode ini, ilmu sosial sedang mengalami krisis. Kalimat pembuka artikel ini sudah menunjukkan permasalan tersebut. Krisis yang dimaksud adalah kuatnya egoisme disiplin yang menganggap dirinya sebagai paling bisa merepresentasikan kajian ilmu sosial. Braudel menyadari bahwa terhadap disiplin tetangga seperti ekonomi, etnografi, sosiologi, psikologi, linguistik, demografi, geografi, dan statistik, ilmu sejarah kemudian mendapat cara baru dalam melihat persoalan. Dan melalui artikel inilah, ia ingin menawarkan sesuatu (Braudel, 1958: 11; Revel, 1978: 15). Semua itu dilakukan supaya "ilmu-ilmu sosial berhenti berdebat seputar batasan-batasan kajiannya, tantang apa yang ilmu sosial dan bukan, apa yang struktur dan bukan", dan lebih memfokuskan "mencari benang merah dari penelitian kita" yang kemudian bisa menjadi dasar untuk melakukan "program penelitian bersama" (Braudel, 1958: 37).

Kedua, artikel ini lahir dari tradisi mazhab Annales. Mazhab ini lahir dari sebuah perenungan mendalam terkait disiplin sejarah dan profesi sejarawan. Program intelektual yang ditawarkannya disebarluaskan melalui jurnal Annales secara agresif. Pertama, ia diinisiasi oleh dua tokoh yang tidak dikenal pada masa itu - Lucien Febvre dan Marc Bloch. Kedua, keduanya adalah profesor muda di Universitas

\footnotetext{
${ }^{4}$ Gagasan-gagasan tentang sejarah yang harus ikut terlibat dalam persoalan masa kini bisa dibaca dalam kumpulan artikel Lucien Febvre dalam buku berjudul A New Kind of History (1973). Artikel berjudul "Vers une autre histoire", terbit tahun 1949, yang kemudian dijadikan judul buku kumpulan tulisan ini, cukup merepresentasikan apa yang menjadi semangatnya untuk memperbarui disiplin ilmu sejarah.
} 
Straasburg, sebuah universitas yang tidak masuk dalam peta kekuatan pemikiran di Prancis. Dengan latar belakang yang marjinal ini, mereka mencoba melawan dua hal: dominasi Universitas Sorbonne di Paris dan kemapanan ilmu sejarah. Hal itulah yang kemudian membuat kritik yang disampaikannya menjadi demikian agresif (Revel, 1979: 1362). Dalam ungkapan Revel, Annales berkaitan dengan "history as a problem, the search for models, the long term, the convergence of the social sociences, and even the encouragement of collective work, the research project, which was to play such a large role in subsequent historiography" (Revel, 1978: 12).

Artikel Braudel tentang longue durée terbit di rubrik "Débats et Combats", sebuah rubrik yang dari namanya saja sudah menawarkan polemik: debat. Di dalam rubrik ini, percobaan untuk menawarkan perspektif baru dalam melihat sejarah dan ilmuilmu sosial kerap dimunculkan. Pada tahun 1960, Braudel yang pada saat itu telah menjadi redaktur Annales, menerbitkan kembali artikel François Simiand "Méthode historique et science sociales", sebuah artikel provokatif, yang terbit pertama kali pada thaun 1903 di jurnal Revue de synthèse historique, sebagai sebuah kritik terhadap buku Charles Seignobos, La méthode historique appliquée aux sciences sociales, terbit tahun 1901. Di dalam artikel tersebut, Simiand meyampaikan kritik terhadap konsep sejarah yang ia namai sebagai "historisante", yang dalam istilah lain juga kerap disebut sebagai sejarah yang positivistik. Bisa dikatakan bahwa apa yang menjadi fokus kritiknya adalah model penulisan sejarah yang mengklaim dirinya paling ilmiah yang bertujuan untuk mengumpulkan informasi sebanyak mungkin dan hanya dengan cara seperti itulah pengetahuan sejarah didefinisikan. ${ }^{5}$ Namun demikian, dari artikel inilah, agenda politik ilmu pengetahuan Annales lahir: sejarah yang berorientasi kepada permasalahan (histoire-problème), pencarian model, konvergensi ilmu-ilmu humaniora, dan juga ajakan untuk melakukan pekerjaan penelitian secara kolektif.

Sejak awal kelahirannya, Annales memiliki semangat perlawanan: terhadap kemapanan institusi universitas dan kemapanan disiplin ilmu sejarah. Immanuel Wallerstein dalam pidato pembukaan konferensi tentang Mazhab Annales di New York mengatakan bahwa "kami merayakan (keberhasilan) Annales, bukan karena inovasinya, tetapi karena ia telah melakukan perlawanan, dan melawan dengan baik" (Wallerstein, 1978: 6) ${ }^{6}$. Dalam kerangka inilah tulisan Braudel perlu dilihat.

Ketiga, artikel Braudel harus dilihat dalam perkembangan ilmu-ilmu sosial di tahun 1950-an, sebuah periode yang dalam bahasa François Dosse disebut sebagai "l'explosion des sciances sociales" - ledakan ilmu-ilmu sosial. Pada masa ini, ilmuilmu sosial mengalami perkembangan yang cukup signifikan. Universitas Sorbonne membuka posisi untuk profesor sosiologi, psikologi sosial, dan psikologi pada periode ini. Pada tahun 1958, program sarjana strata satu dan doktoral di bidang

\footnotetext{
${ }^{5}$ Sebetulnya, dalam artikel tersebut François Simiand tidak mengidentifikasi dan mengurai lebih jauh apa yang ia maksud dengan sejarah yang "historisante". Sebagaimana sebuah teks yang memang ditujukan untuk berpolemik, ia menyeragamkan praktik penulisan yang ada. Meskipun demikian, kritik yang disampaikannya sangat baik untuk dicermati karena kemudian menjadi landasan lahirnya mazhab Annales itu sendiri. Untuk informasi lebih jauh, lihat (Revel, 1979, p. 1363)

${ }^{6}$ Untuk uraian tentang sejarah Mazhab Annales, lihat Traian Stoianovich, French Historical Method: The Annales Paradigm, 1976 dan Peter Burke, The French Historical Revolution: The Annales School, 1929-89, 1990.
} 
sosiologi juga dibuka. Pada periode ini, angka penjualan buku Cours de linguistique karya Ferdinand de Saussure yang terbit pertama tahun 1928 dan selama tiga puluh tahun jumlah penjualannya tidak pernah melewati angka 15.000, pada tahun 1960-an angkanya mencapai 10.000. Begitu pula dengan buku Introduction à la psychanalyse karya Sigmund Freud, antara tahun 1962 dan 1967, jumlah yang terjual mencapai 165.000. Di atas itu semua, buku Tristes Tropiques karya Claude Lévi-Strauss, terbit tahun 1955, mencapai publik yang sangat luas (Dosse, 2010: 100-101; lihat juga Delacroix (et al.), 2007).

Pada tahun 1950-an, strukturalisme sebagai sebuah gerakan juga berkembang di bidang antropologi, lingustik, psikoanalisis, dan bidang yang lain. Lévi-Strauss yang menerbitkan Anthropologi structural pada tahun 1958 merupakan figur sentral dalam perkembangan ini. Tantangan yang diberikan kepada disiplin sejarah cukup keras. Pertama, ia mengatakan bahwa disiplin sejarah hanya berurusan dengan pengumpulan data, persoalan empiris, sementara antropologi berurusan dengan persoalan konseptual. Kedua, konsekuensi dari itu, disiplin sejarah tidak akan memberi banyak kontribusi terhadap ilmu kemanusiaan, dan di titik ini Lévi-Strasuss juga mengampanyekan apa yang dinamakan dehistorisasi. Nah, dalam konteks perkembangan ilmu-ilmu sosial inilah Braudel menulis artikel, untuk memosisikan kembali ilmu sejarah di hadapan ilmu-ilmu sosial yang lain (Dosse, 2010: 102-105; Lihat juga Wallerstein, 2009: 159). Ini penting karena berkaitan dengan apa yang menjadi ambisi Annales: konvergensi ilmu-ilmu sosial dengan sejarah sebagai pusatnya.

\subsection{Longue durée sebagai Paradigma}

Telah disampaikan bahwa artikel Braudel tentang longue durée yang terbit tahun 1958 merupakan jawaban atas kritik terhadap disiplin sejarah oleh ilmu sosial lain, terutama Lévi-Strauss dengan antropologi strukturalnya. Sebagaimana tampak di dalam judul, persoalan waktu menjadi fokus analisisnya. Dengan mengemukakan konsep longue durée ia membangun suatu paradigma disiplin ilmu sosial dengan meletakan disiplin sejarah sebagai pusatnya. Ada dua nilai yang ingin ditawarkan oleh Braudel. Pertama, longue durée yang berurusan dengan durasi yang panjang, identik dengan sebuah tatanan yang mengalami sedikit perubahan dalam waktu. Dengan kata lain, ia sedang berbicara tentang sesuatu yang struktural. Kedua, struktur yang dimaksud berbeda dari struktur dalam kerangka ilmuan sosial yang memaknainya sebagai "sebuah organisasi, satu koherensi berbagai hubungan yang tetap antara realitas dan himpunan sosial". Lebih dari sekedar melihatnya sebagai sebuah himpunan, suatu bangunan, Braudel memaknai struktur sebagai sebuah "kenyataan di mana waktu hanya bisa perlahan terkikis yang terus akan berlangsung untuk waktu yang lama" (Braudel, 1958: 15). Demikian, lebih dari sekedar melihat sebuah bangunan tetap yang tidak berubah, yang berada di luar waktu, Braudel melihatnya sebagai sebuah bangunan yang terbentuk di dalam waktu dengan proses yang sangat panjang. Dengan kata lain, melalui longue durée, Braudel menambahkan aspek waktu dalam analisis struktural.

Bagaimana ia melakukan itu?

Pertama-tama, sebagaimana jelas disebutkan di judul, tulisan Barudel ini berfokus kepada perlu dijelaskannya tentang apa yang dimaksud dengan durée itu 
sendiri, mengingat kata tersebut juga terdapat di dalam judul artikel Braudel dan menjadi fokus analisis, terutama karena ia juga membahas tiga jenis durée di dalam artikel tersebut. Wallerstein mengatakan bahwa Braudel menggunakan kata durée di dalam artikel tersebut setidaknya untuk tiga makna: durasi, kontinuitas, dan temporalitas. Meskipun demikian, makna durée sebagai temporalitas lebih sering digunakan di dalam artikel ini (Wallerstein, 2009: 160-161).

Braudel membagi durée menjadi tiga bagian: durée yang pendek, sedang, dan panjang. Untuk yang pertama, ia menamai itu sebagai événement, yang kedua ia sebut sebagai conjoncturel, dan yang terakhir yang menjadi fokus analisis tulisannya adalah structure atau longue durée. Demikian, dalam kerangka Braudel, waktu memiliki tiga lapisan, yang darinya ia juga melihat tatanan realitas sosial secara hierarkis.

Di lapisan paling atas, terdapat sebuah aliran waktu yang berlangsung sekejap. Ini berlaku bagi peristiwa-peristiwa individu yang bisa sering menjadi perhatian para sejarawan. "Peristiwa adalah sebuah ledakan, sesuatu yang memiliki 'suara kebaruan' (nouvelle sonnante) sebagaimana mereka sebut di abad ke-16. Di tengah asap [ledakan] yang mengaburkan, ia tetap ada di dalam kesadaran orang-orang sekarang, tapi tidak bertahan lama, ia akan menghilang seiring terlihatnya sumber apinya", tulis Braudel. Kutipan tersebut penuh perumpamaan, sesuatu yang cukup khas dalam tulisan-tulisannya. Untuk membuatnya lebih kongkret, ia mengatakan bahwa peristiwa merupakan sesuatu yang identik dengan "jangka pendek (le temps court), berada dalam skala individu, kehidupan sehari-hari, ilusi-ilusi dan kesadaran jangka pendek kita. Ini adalah jenis waktu yang lebih disukai oleh para penulis babad dan para jurnalis". Contoh-contoh yang ditunjukan oleh Braudel adalah seperti peristiwa kebakaran, kecelakan kereta, banjir, dan peristiwa pembunuhan. Menurut Braudel, para ilmuan sosial sangat menentang waktu jangka pendek ini sebab "waktu jangka pendek itu yang paling berubah, jenis waktu yang paling menyesatkan" (Braudel, 1958: 12).

Di bawahnya, ada peristiwa-peristiwa yang berlangsung dalam durasi sedang. Jika sebelumnya para sejarawan hanya berurusan dengan peristiwa yang berlangsung sehari atau satu tahun, itu memang bisa dilakukan jika seseorang sedang merekonstruksi sebuah peristiwa politik. Namun, jika ada upaya untuk mengetahui kurva naik turunnya harga, pertumbuhan demografis, trend dalam pemberian upah pekerja, misalnya, semua ini hanya bisa dilakukan jika jangka waktunya diperpanjang. Untuk hal ini, model baru dalam menarasikan sejarah diperlukan. Braudel menamai itu sebagai "'resitatif' dari fase siklus (conjuncture), siklus, bahkan 'antar siklus' yang menawarkan kepada kita jangka waktu puluhan tahun, seperempat abad, dan yang paling panjang, setengah abadnya siklus kondratif yang klasik" (Braudel, 1958: 14). Dengan memberi penekanan pada durasi sedang, Braudel sedang mencoba memberi penjelasan dengan mengikuti model yang ditawarkan oleh para sejarawan ekonomi seperti Ernest Labrousse pada masa itu. Menurutnya, dengan memberi penekanan pada jangka waktu siklus ini, penjelasan terhadap realitas sosial bisa menjadi lebih tergali. Meskipun demikian, analisis ini belumlah cukup, ia masih perlu menggali lebih dalam lagi.

Pada lapisan yang paling dasar, yang kemudian menjadi prakondisi dari dua lapis di atasnya, adalah sebuah tatanan yang berlangsung dalam durasi yang cukup panjang, yang jika diamati seperti tidak ada perubahan seperti dalam perubahan alam geografis dan sampai batas tertentu adalah mentalitas. Pada titik ini, Braudel 
sedang berbicara tentang struktur, dalam pengertian sejarawan tentu saja. Ia memberi ilustrasi tentang hal ini dengan menunjukkan bahwa terdapat hambatan geografis, sesungguhnya "manusia itu terpenjara oleh waktu yang berlangsung berabad-abad, keadaan iklim, tumbuh-tumbuhan, populasi binatang, kebudayaan, terpenjara oleh sebuah keseimbangan yang terbentuk secara perlahan, yang ia tidak bisa melepaskan diri darinya tanpa menimbulkan permasalahan terhadap semuanya" (Braudel, 1958: 15). Proses yang berjalan sangat lambat, tetapi ikut memengaruhi kehidupan individu. Analisis pada aspek inilah yang sangat penting untuk melengkapi dua lapisan waktu yang lain. Meskipun demikian, longue durée merupakan satuan waktu yang paling sulit untuk dilakukan. Bagi sejarawan yang ingin melakukannya, "ia harus mau menerima perubahan gaya dan sikap, sebuah cara berpikir yang berputar, sebuah konsep baru tentang kehidupan sosial. Ia juga perlu mengetahui lebih jauh tentang temporalitas yang bergerak lebih lambat, hampir tidak bergerak sama sekali" (Braudel, 1958: 18). Demikian, perubahan dalam cara kerja sejarawan perlu dilakukan.

Dengan mengemukakan tatanan sosial yang seperti itu, Braudel memiliki ambisi untuk membuat suatu sintesis dari kesatuan realitas yang diasumsikan memiliki makna tertentu. Dengan memberi penekanan terhadap pentingnya longue durée atau struktur sebagai paradigma dalam penelitian sejarah, ia tidak bermaksud meminggirkan dua jenis waktu yang lain, "jangka waktu pendek" dan "jangka waktu sedang". Lebih dari itu, ia berharap agar ketiganya dilakukan sebagai satu kesatuan. Itulah sebabnya kemudian kajian ini kerap dinamai sebagai "sejarah total" atau "sejarah global". Dalam kaitannya dengan ilmu-ilmu sosial yang lain, ia juga ingin menjadikan bahwa longue durée sebagai ruang pertemuan antara berbagai disiplin ilmu sosial. Pada titik ini, longue durée sebetulnya tidak bisa dikuantifikasi sebagai ukuran panjang waktu tertentu, tetapi lebih merupakan sebuah analisis struktural terhadap realitas (historis) tanpa meninggalkan aspek waktu di dalamnya yang mengandaikan perubahan struktural itu sendiri, walaupun berjalan sangat lambat.

\subsection{Reaksi: dari histoire nouvelle sampai ke microstoria}

Telah disampaikan bahwa Fernand Braudel menulis artikel tentang longue durée dalam semangat mazhab Annales yang terus mencoba mendefinisikan sejarah sebagai sebuah disiplin ilmu yang terus kontekstual dengan persoalan kontemporer. Oleh karena itu, sekali pun posisi Braudel pada tahun 1950-an cukup kuat secara keilmuan, karena ia merepresentasikan mazhab Annales itu sendiri (di tahun 1959 ia ditunjuk menjadi pemimpin jurnal) dan juga kuat secara politik karena ia merupakan profesor di College de France dan Ecole Pratiques Des Hautes Etudes, pada bagian keenam yang mengkhususkan pada pengkajian ilmu-ilmu sosial, ia tetap tidak menjadikannya sebagai anti kritik. Ini ia akui sendiri ketika generasi baru sejarawan muncul seperti Emmanuel Le Roy Ladurie, Jacques Le Goff, dan André Burguière untuk menyebut beberapa nama - dengan semangat baru dalam praktik penulisan sejarah, dengan tema-tema yang baru, ia tidak berkeras mempertahankan model penulisan sejarah menurut dirinya. Lebih dari itu, sekalipun kurang setuju, ia tetap memberi ruang kepada para sejarawan dari generasi baru ini. "Saya menyerahkan Annales kepada para penerus saya. Semuanya terserah mereka. Setiap generasi memiliki kewajibannya masing-masing! Jika saya ingin Annales tetap hidup, maka ia 
tidak bisa diharuskan mengikuti Lucien Febvre, Marc Bloch, atau Fernand Braudel. Ia harus dibiarkan mengalir", tulis Braudel (Braudel, 1978: 255-256).

Generasi baru sejarawan setelah Braudel inilah yang kemudian mengemukakan apa yang dinamakan sebagai nouvelle histoire. Ada dua sifat umum yang penting dicatat darinya. Pertama, semua bentuk histoire nouvelle adalah percobaan untuk merekonstruksi sejarah total. Gagasan ini jelas bisa ditelusuri sampai ke Braudel sebagaimana telah dijelaskan sebelumnya, tetapi dengan catatan kritis yang akan dibahas nanti. Kedua, histoire nouvelle merupakan ikhtiar untuk memperluas pemaknaan dari apa yang dinamakan sebagai dokumen sejarah. Ini merupakan konsekuensi dari poin pertama, karena dengan upaya merekonstruksi sejarah total, sumber sejarah, dokumen sejarah, harus didefinisikan ulang. Itulah sebabnya upaya tersebut tidak akan terwujud seandainya pemahaman terkait apa yang dinamakan sumber sejarah dilakukan secara sempit (Le Goff, 1978: 37-38).

Longue durée juga masih menjadi kategori analisis dalam histoire nouvelle. Perhatian terhadap sesuatu yang bergerak lambat, sebuah kekuatan yang berada di kedalaman, hanya bisa dielaborasi dalam kajian dengan periode yang panjang karena sebuah "sistem ekonomi dan sistem sosial hanya akan mengalami perubahan secara perlahan". Oleh karena itu, kajian terhadap sesuatu yang berubah secara perlahan ini yang selama beberapa dasawarsa ini disebut sebagai struktur dalam pengertian jamak merupakan sesuatu yang tidak bisa diabaikan. Meskipun demikian, penekanan terhadap proses harus tetap diutamakan. Ini penting untuk menghindari ungkapan berbahaya seperti "sejarah yang hampir tidak bergerak" (histoire presque immobile) yang pernah diulas oleh Braudel dan "sejarah yang tidak bergerak" (histoire immobile) dari Emmanuel Le Ladurie. Sebab, bagaimana pun, sejarah itu bergerak, dan histoire nouvelle harus lebih bisa memiliki kemampuan untuk mengurai proses perubahan (Le Goff, 1978: 54-55).

Michel Vovellle mengatakan bahwa kesuksesan longue durée adalah kemampuannya memodifikasi wilayah kajian disiplin sejarah. Ada dua hal yang berubah: metode dan teknik penelitian. (Vovelle, 1978: 80). Pertama berkaitan dengan metode, sejarah longue durée menggeser fokus dari penelitian gerakan sosial ke struktur sosial. Para sejarawan lebih memilih menganalisis strukur sosial masyarakat urban atau pedesaan, misalnya, untuk mengetahui bagaimana dinamika masyarakat di kedua ruang itu, sebuah proses yang berjalan lambat dalam jangka waktu yang panjang, sehingga tatanan yang membentuk dan dibentuk oleh para agen di dalamnya melembaga. Penelitian terhadap struktur sosial ini juga telah membuka jalan kepada fokus penelitian yang lain: sejarah mentalitas yang, menurut Vovelle, merupakan wilayah penelitian yang khas longue durée (Vovelle, 1978: 84-85). Sejarah mentalitas longue durée memiliki kemampuan mengungkap sejarah evolusioner yang tidak tampak (Vovelle, $1978: 86$ ).

Berkaitan dengan teknik, Vovelle menjelaskan bahwa gagasan longue durée telah membuka ruang untuk mempertanyakan kembali tentang apa yang disebut dengan sumber sejarah. Pertama, sumber dokumen tertulis - dalam pengertian laporanlaporan resmi yang mengulas satu persoalan tertentu - tidak lagi menjadi satusatunya sumber sejarah. Sumber sejarah tidak lagi diperlakukan sebagai sesuatu yang memuat informasi yang spesifik di masa lalu. Lebih dari itu, sekumpulan sumber atau sebuah seri dokumen juga bisa dipergunakan sebagai sumber informasi bukan untuk mencari suatu peristiwa yang spesifik, tetapi untuk melihat kecenderungan- 
kecenderungan tertentu atau peristiwa yang berulang, yang darinya akan tampak perubahan-perubahan dari suatu kecenderungan di dalam masyarakat. Kedua, inventaris ex-voto atau benda persembahan untuk orang suci, merupakan dokumen yang sangat kaya akan informasi. Ini berkaitan dengan kemampuan pembacaan ikonografis tentu saja. Meletakan ex-voto secara serial dalam waktu yang cukup panjang akan menyajikan informasi yang cukup penting terkait cara bagaimana kecenderungan praktik keagamaan dalam masa yang cukup panjang (Vovelle, 1978: 88-91).

Sekalipun pengaruh longue durée ini cukup kuat, tapi kritik terhadapnya juga tidak sedikit. Salah satu yang kerap menjadi sasaran kritik adalah hilangnya "peristiwa" dalam kajian sejarah. Terkait hal ini, Braudel memang jelas menganggap peristiwa sebagai sesuatu yang kurang penting dibanding dengan dua struktur waktu yang lain: conjoncture dan longue durée. Tapi itu tidak berarti bahwa ia harus diabaikan. Braudel menulis:

Peristiwa merupakan kesementaraan dari sejarah; melewati tahapannya laksana kunang-kunang, nyaris tidak dilirik sebelum kembali ke kegelapan dan seringkali tidak terlupakan. Setiap peristiwa, betapapun singkatnya, harus memastikan, sumbangan yang harus diberikan, yang menerangi sudut gelap atau bahkan pemandangan sejarah yang luas. Juga bukan hanya sejarah politik yang paling diuntungkan, karena setiap lanskap sejarah - baik politik, sosial ekonomi, bahkan geografis - diterangi oleh suar yang terputusputus dari peristiwa tersebut... Aku sama sekali bukan musuh bebuyutan peristiwa

events are the ephemera of history; they pass across its stage like fireflies, hardly glimpsed before they settle back into darkness and as often as not into oblivion. Every event, however brief, has to be sure, a contribution to make, lights up some dark corner or even some wide vista of history. Nor is it only political history which benefits most, for every historical landscape - political, economic social, even geographical - is illumined by the intermittent flare of the event.... I am by no means the sworn enemy of the event (Braudel dalam Tomich, 2011: 57).

Dalam hal ini, Braudel jelas mengatakan bahwa ia bukan merupakan musuh "peristiwa". Hanya saja, penekanan terhadap pentingya struktur sering dianggap sebaliknya.

Microstoria merupakan respons terhadap itu. Microstoria atau microhistory itu sendiri merupakan bentuk penulisan sejarah yang dikembangkan oleh para sejarwan Italia pada tahun 1960-an. Mazhab ini lahir sebagai respons terhadap cara penulisan sejarah braudelian (Tomich, 2011: 62; lihat juga Ginzburg, 2012 terutama halaman 193 214). Mereka adalah para sejarawan Italia yang berkumpul dalam sebuah jurnal bernama Quaderni Storici. Agenda utama mereka adalah memberi perhatian terhadap individu, merekonstruksi sebuah peristiwa yang berlangsung dalam durasi pendek, mengoperasikan pembacaan analitis, untuk menghasilkan sebuah kesimpulan umum. Kesimpulan ini lahir dari pembacaan data empiris yang sangat banyak. Kondisi material Italia sangat memungkinkan itu. Arsip-arsip gereja memiliki 
kekayaan berlimpah yang merekam praktik kehidupan sehari-hari masyarakat di abad pertengahan. Itulah, dalam kasus microstoria, kelahirannya dimungkinkan oleh dua hal: respon terhadap penulisan sejarah braudelian dan keberadaan arsip yang berlimpah.

Seperti mazhab Annales, microstoria juga sering disalahpahami sebagai satu kesatuan sistem pemikiran yang seragam dan sudah jadi. Sebaliknya, ia adalah medan percobaan. Giovanni Levi mengatakan: "Microhistoria pada dasarnya merupakan praktik historiografis sementara referensi teoretisnya beragam, dan sedikit banyak ekletis. Metode ini, pertama dan utama, memang berkaitan dengan prosedur rinci yang aktual yang merupakan kerja sejarawan, maka microhistoria tidak dapat didefinisikan dalam hubungannya dengan dimensi mikro pokok bahasannya" (Microhistory is essentially a historiographical practice whereas its theoretical references are varied and, in a sense, eclectic. The method is in fact concerned first and foremost with the actual detailed procedures which constitute the historian's work, so microhistory cannot be defined in relation to the micro-dimensions of its subject-matter) (Levi, 1991: 94). Dalam rumusan yang lebih spesifik, Carlo Ginzburg dan Carlo Poni mengatakan bahwa microstoria adalah sebuah prosopografi masal yang bertujuan untuk menampilkan seri dari studi kasus. Demikian, penelitian serial dari korpus sumber tetap dilakukan - yang membedakannya dari prosopografi klasik -, dengan tujuan menampilkan kasus yang beragam sebagai sebuah model. Selain itu, hal ini juga bisa dilakukan dengan cara membaca "pengecualian normal" dari sebuah kasus. Contoh: di antara seri dokumen yang memberitakan hal yang sama, muncul satu dokumen dengan narasi berbeda; hal ini bisa dijadikan sebuah tanda, representasi dari sesuatu yang mendalam (Ginzburg \& Poni, 1981: 4).

Dengan memberi penekanan terhadap studi tentang individu, microstoria sebetulnya berupaya untuk mencari bentuk yang paling realistik dari praktik kehidupan sosial. Ia tidak percaya terhadap mekanisme otomatis dari hubungan yang deterministik antara individu dan struktur. Pada titik ini, strategi individu dan kolektif, juga pilihan-pilihan dan negosiasi-negosiasi yang dilakukannya bisa dilihat dalam hubungannya dengan konteks yang sangat spesifik, tetapi tidak dapat direduksi kepadanya (Tomich, 2011: 63).

Sebagaimana yang telah disampaikan, sebetulnya Braudel tidak benar-benar memusuhi "peristiwa". Dalam kaitan dengan hal ini, penting membaca apa yang dikatakan oleh Paul Ricœur tentang hal ini. Ia secara khusus menganalisis buku La Méditerranée et le Monde méditerranéen à l'époque de Philippe II, untuk melihat sejauh mana peristiwa diperlakukan dalam karya tersebut. Pertama, peristiwa yang diulas dalam buku tersebut, yang menjadi pokok pembahasan di bagian ketiga, bukanlah peristiwa dalam pengertian peristiwa dalam sejarah tradisional, yang hanya berkaitan dengan peristiwa politik, diplomasi, dan peperangan. Bagi Braudel peristiwa-peristiwa yang dianalisis lebih merupakan sebuah representasi dari tumpukan terdalam realitas sejarah. Ia merupakan sebuah gejala dari sebuah pergerakan yang terdapat di kedalaman. Kedua, apa yang ia lakukan lebih merupakan sebuah upaya untuk menstrukturasi peristiwa, dan karenanya model penulisan sejarah yang dilakukannya tidak dipenuhi oleh tanggal-tanggal. Ia juga tidak membagi peristiwa-peristiwa itu dalam sebuah periodisasi seperti umumnya dilakukan oleh para sejarawan, tetapi meletakannya sebagai bahan material yang membentuk struktur. Ketiga, apa yang dilakukan oleh Braudel lebih merupakan 
penemuan bentuk baru alur sebuah penceritaan sejarah. Ia melakukannya dengan mengombinasikan berbagai macam alur yang terdapat di berbagai temporalitas, kronologi, dan semuanya diikat dalam sebuah struktur (Ricœur, 1983: 296-301). Semua itu dilakukan sebagai upaya untuk mengkritik dua jenis waktu yang sangat panjang sekali, yang memberi kesan tidak ada pergerakan sama sekali - model analisis yang kerap dilakukan oleh para ilmuan sosial; di sisi lain, ia juga mengkritik jangka waktu pendek, yang menjadi model dalam praktik penulisan sejarah yang hanya memberi penekanan pada peristiwa.

Berdasarkan ketiga poin ini, bagi Braudel peristiwa tetap merupakan elemen yang sangat penting dalam penceritaan sejarah. Hanya saja keberadaannya harus selalu diletakkan dalam sebuah struktur yang lebih luas dan melihatnya sebagai representasi dari sesuatu yang berada di kedalaman karena, jika benar Braudel tidak menganggap penting peristiwa, ia tentu saja tidak akan mengakhiri narasinya tentang La Méditerranée dengan kematian Philippe II pada tanggal 13 September 1598 (Ricœur, 1983: 298). Itulah sebabnya apa yang dilakuan oleh Braudel lebih merupakan sebuah strategi narasi.

\section{PENUTUP}

Artikel ini dimulai dengan pertanyaan tentang apa yang dimaksud dengan longue durée, apakah ia selalu berkaitan dengan sebuah durasi, dan jika iya, seberapa lama sesuatu bisa itu bisa dikatakan longue durée? Pertanyaan-pertanyaan ini diajukan untuk melihat lebih jauh bagaimana konteks kelahiran longue durée itu sendiri, bagaimana ia dioperasikan dalam praktik penulisan sejarah, dan bagaimana reaksi terhadapnya bermunculan. Pembahasan artikel ini sudah menunjukkan bahwa istilah longue durée lahir dari sebuah ambisi untuk menyatukan kajian ilmu-ilmu sosial di bawah bendera disiplin sejarah. Ambisi itu sendiri lahir dari adanya krisis di dalam ilmu-ilmu sosial yang semakin mempertebal batasan-batasan keilmuannya, yang pada akhirnya kajian-kajiannya tidak banyak memberi kontribusi terhadap persoalan yang dihadapi dalam keseharian. Semua itu dilakukan dengan menjadikan longue durée yang juga dimaknai sebagai struktur sebagai pertemuan antara berbagai ilmu-ilmu sosial. Demikian, istilah longue durée itu sendiri tidak selalu berkaitan dengan suatu temporalitas, melainkan sebuah cara melihat realitas yang terbentuk secara perlahan dalam periode yang panjang, yang kemudian menjadi prakondisi atas persoalan-persoalan yang muncul di permukaan. Pada titik ini, longue durée jelas tidak bisa diukur sebagai satuan waktu yang terkuantifikasi.

Demikian, longue durée merupakan sebuah metode untuk menganalisis realitas sosial yang lahir dari sebuah krisis ilmu-ilmu sosial. Belakangan ini, ketika ilmu-ilmu sosial sedang dihadapkan kepada krisis, dengan banyaknya upaya mengurangi posisi-posisi di universitas dan anggaran penelitian, pembahasan mengenai longue durée kembali mengemuka. Setidaknya itulah yang tampak dalam jurnal Annales volume 70, nomor 2, tahun 2015 dengan isu khusus tentang "longue durée en débat", longue durée dalam perdebatan. Volume ini dibuka dengan sebuah artikel berjudul "Le retour de la longue durée: une perspective anglo-américaine", ditulis oleh David Armitage, profesor sejarah di Universitas Harvard, dan Jo Guldi, profesor sejarah dari Universitas Brown. Dalam artikel tersebut, kedua sejarawan Amerika ini 
berpendapat pentingnya kembali menggunakan perspektif longue durée dalam kajian sejarah, agar disiplin ini bisa lebih fungsional, telibat dalam perdebatan permasalahan-permasalahan kontemper (Armitage \& Guldi, 2015a). Setahun sebelumnya, kedua sejarawan ini juga menerbitkan The History Manifesto, sebuah buku yang juga menekankan pentingnya perspektif longue durée dalam kajian sejarah (Armitage \& Guldi, 2014).

Terlibat dalam perdebatan mengenai longue durée cukup perlu dilakukan karena ia juga menjadi pintu masuk ke dalam perdebatan apa yang dinamakan sejarah global, sebuah perspektif yang melihat peristiwa sejarah sebagai satu kesatuan yang tidak terbatas ruang administratif seperti sebuah negara, misalnya. Meskipun demikian, perdebatan mengenai longue durée dalam hubungannya sejarah global memerlukan kajian tersendiri, yang darinya mungkin akan bisa muncul gagasan baru untuk menyegarkan kajian dalam disiplin sejarah. Selain itu, tentang bagaimana perspektif longue durée dalam hubungannya dengan historiografi Indonesia juga merupakan subjek yang belum dibahas. Padahal hal tersebut penting dilakukan untuk meletakkan praktik penulisan sejarah di Indonesia dalam hubungannya dengan praktik penulisan sejarah di tingkat global. Namun demikian, persoalan ini juga harus menjadi penelitian yang lain lagi.

\section{DAFTAR PUSTAKA}

Armitage, David \& Guldi, Jo. 2015a. “Le retour de la longue durée: Une perspective anglo-américaine". Annales. Histoire, Sciences Sociales, 70(02), hlm. 289-318.

Armitage, David \& Guldi, Jo. 2014. The History Manifesto. Cambridge: Cambridge University Press Armitage, David \& Guldi, Jo. 2015b. "Pour une 'histoire ambitieuse'”. Annales. Histoire, Sciences Sociales, 70(02), hlm. 367-378.

Braudel, Fernand. 1958. "Histoire et Sciences Sociales: La longue durée". Annales. Economies, Sociétés, Civilisations, 13 (4), hlm. 725-753.

Braudel, Fernand. 1972. "Personal Testimony". The Journal of Modern History, 44(4), hlm. 448-467.

Braudel, Fernand. 1978. "En Guise de Conclusion [with Discussion]". Review (Fernand Braudel Center), 1 (3/4,), hlm. 243-261.

Braudel, Paule. 1992. “Les origines intellectuelles de Fernand Braudel: Un témoignage". Annales. Histoire, Sciences Sociales, 47 (1), 237-244.

Burke, Peter. 1990. The French Historical Revolution: The Annales School, 1929-89. Cambridge: Polity Press.

Delacroix, Chistian (eds.). 2007. Les courants historiques en France: XIXe - XXe siècle. Paris: Gallimard.

Dosse, François. 2010. L' histoire en miettes: Des "Annales" à la "nouvelle histoire." Paris: La Découverte.

Dosse, François. 2014. "Structuralisme" dalam Delacroix (eds.) Historiographies: Concepts et débats. Paris: Gallimard. hlm. 883-893.

Febvre, Lucien. 1949. "Vers une autre histoire". Revue de Métaphisique et de Morale, 54 (3/4), hlm. 225-247. 
Febvre, Lucien. 1973. A New Kind of Hisotry. New York: Harper \& Row.

Ginzburg, Carlo. 2012. Threads and traces true, false, fictive. Berkeley: University of California Press.

Ginzburg, Carlo \& Poni, Carlo. 1981. “La micro-histoire”. Le Débat, 17(10), hlm. 133136.

Kartodirdjo, Sartono. 1993. Pendekatan Ilmu Sosial dalam Metodologi Sejarah. Jakarta: Gramedia.

Kuntowijoyo. 2008. Penjelasan sejarah (Historical explanation). Sleman, Yogyakarta: Tiara Wacana.

Le Goff, Jacques. 1978. "L'histoire nouvelle" dalam Le Goff (Ed.), La nouvelle histoire. Paris: Retz-C.E.P.L. hlm. 35-75.

Levi, Giovanni. 1991. "On Microhistory" dalam Burke (Ed.), New Perspectives on Historical Writing. Cambridge: Polity Press. hlm. 93-115.

Noiriel, Gérard. 2003. Penser avec, penser contre: Itinéraire d'un historien. Paris: Belin.

Pomian, Krzystof. 1978. "L'histoire des structures" dalam Le Goff (Ed.), La nouvelle histoire. Paris: Retz-C.E.P.L. hlm. 109-136.

Revel, Jacques. 1978. “The Annales: Continuities and Discontinuities”. Review (Fernand Braudel Center), 1 (3/4,), hlm. 9-18.

Revel, Jacques. 1979. "Histoire et sciences sociales: Les paradigmes des Annales". Annales. Histoire, Sciences Sociales, 34 (6), hlm. 1360-1376.

Rheinberger, Hans-Jörg. 2010. On historicizing epistemology: An essay. Stanford: Stanford University Press.

Ricœur, Paul. 1983. Temps et récit I. Paris: Seuil.

Stoianovich, Traian. 1976. French Historical Method: The Annales Paradigm. Ithaca dan London: Cornell University Press.

Tomich, Dale. 2011. “The Order of Historical Time: The Longue Durée and MicroHistory". Almanack, (2), 52-65. https://doi.org/10.1590/2236-463320110204, diakses 16 Desember 2019.

Vovelle, Michel. 1978." L'histoire et la longue durée" dalam Le Goff (Ed.), La nouvelle histoire. Paris: Retz-C.E.P.L. hlm. 77-108.

Wallerstein, Immanuel. 1978. "Annales as Resistance". Review (Fernand Braudel Center), 1(3/4,), hlm. 5-7.

Wallerstein, Immanuel. 2009. "Braudel on the Longue Durée: Problems of Conceptual Translation". Review (Fernand Braudel Center), 32 (2,), hlm. 155170. 